\title{
Path Analysis: Effect of Gestational Factors, Psychosocial Factors, and Maternal Class-Room Program on Toddler Growth
}

\author{
Gita Ayu Indria'), Bhisma Murti'), Yulia Lanti Retno Dewi²) \\ 1)Masters Program in Public Health, Universitas Sebelas Maret \\ 2)Department of Nutritional, Faculty of Medicine, Universitas Sebelas Maret
}

\begin{abstract}
Background: According to David Barker's fetal origins hypothesis, the period of gestation has significant impacts on the developmental health and well being outcomes for an individual ranging from infancy to adulthood. In the current study, toddler's growth is hypothesized to be affected by various gestational exposure and psychosocial factors at early childhood. In addition, the government has launched the class-room program for mothers of toddlers, which aimed improve maternal ability to raise healthy children. This study aimed to determine the effect of gestational factors, psychosocial, and maternal class-room program on toddler's growth.

Subjects and method: This was an observational analytical study with case-control design. The study was conducted in Banjarnegara, Central Java, Indonesia, from July 29 to August 31, 2016. A total of 120 toddlersaged 3 months to 5 years old along with their mothers were selected for the study by fixed exposure sampling. The exogenous variables were family support, family income, maternal education, maternal physical activity, and maternal participation in the class-room program. The endogenous variables were toddler'sbirthweight, weightfor age, height for age, weight for height. The data were collected with a questionnaire and anthropometric measures. The data were analyzed using path analysis model.

Results: Maternal education $(b=-2.44 ; p<0.001)$, birth weight $(b=0.01 ; p=0.038)$, family support $(b=0.04 ; p=0.048)$, and maternal participation in the class-room program $(b=1.29 ; p=0.007)$, had direct significant effect on toddler's weight for age. Birth weight $(b=0.14 ; p=0.279)$, maternal participation in the class-room program $(b=4.92 ; p=0.020)$, maternal education $(b=-11.76 ; p=$ 0.209) had direct significant effect on toddler's height for age. Birth weight $(b<0.01 ; p=0.047)$, maternal participation in the class-room program $(b=0.01 ; p=0.016)$, family income $(b=-0.01 ; p=$ $0.549)$, maternal education( $b=-0.01 ; p=0.008$ ) had direct significant effect on toddler's weight for height. The goodness of fit statistics for the three outcome variables indicated the goodness of fit of the model specified in the path analysis.
\end{abstract}

Conclusion: Some gestational factors, psychosocial factors, and maternal participation in the class-room have significant effects on toddler's growth.

Keywords: path analysis, gestation period, psychosocial factors, toddler's growth

Correspondence:

Gita Ayu Indria. Masters Program of Public Health, Universitas Sebelas Maret, Jl. Ir. Sutami 36A, Surakarta, 57126, Central Java. Email: gitaindria@gmail.com.

\section{BACKGROUND}

The first thousand days of life, starting from the time of conception to a two-year-old child, is a critical momentum that will determine the quality of a nation's generation. This period is a golden period for children's growth and development. Intervention in the first 1000 days of life will support the process of growth and development effectively. Failure in the first 1000 days of life will result in abnormal physical children, low child's intelligence, weak child's immune system and metabolic disorders as one of the risks of non-communicable diseases (Ministry of Health, 2014; Sentika, 2015). 
Journal of Maternal and Child Health (2016), 1(1): 53-61

https://doi.org/10.26911/thejmch.2017.01.01.08

Growth of children to adulthood is influenced by various factors since the gestation period. These factors include maternal psychosocial condition, maternal education level, maternal economic condition, and maternal work (Barros et al., 2010; Power et al., 2007; Harper, 2002; Laecy et al., 2015). The reduction in mortality and infant illness is a priority of health programs from various countries.

Efforts to improve the health of mothers and children, newborns and children, have become a top priority of the government of Indonesia. This is in line with the goals of the Sustainable Development Goals (SDGs) which are the continuation of the Millennium Development Goals (MDG's) development concept, where the MDG's concept has ended in 2015 and has not reached the target. There are 17 goals and 196 specific targets of SDGs and eight of them are health sector development carried out by the Ministry of Health. The development of the health sector includes efforts to reduce the rate of maternal mortality and underfive mortality, deaths from non-communicable diseases, deaths and injuries from traffic accidents, drug and alcohol abuse, HIV / AIDS control, Tuberculosis, malaria, family planning, contamination and pollution of water, air, land. In addition, it includes Universal Health Coverage and handling of emergency crises. The SDG's from 2016 to 2030 are a joint commitment of the international community that aims for sustainable development (Muller et al., 2015).

Based on the MDG's agreement in 2015 it is expected that the under-five infant mortality rate will decline by two-thirds in the period 2010-2015. Based on that, Indonesia has a committment to reduce infant mortality from 68 to 23 / 1,00o live births, and the infant mortality rate 97 to 32 / 1,000 live births in 2015. Based on the Ind- onesian Demographic Health Survey (IDHS, 2012) the infant mortality rate in Indonesia is still $40 / 1000$ live births.

To achieve the target of reducing the under-five mortality rate in 2015 MDG, which is $32 / 1000$ live births, increasing access and quality of services for newborns (neonatal) and toddlers is the top priority (Ministry of Health, 2014).

One of the government's efforts to improve services for the health of infants and toddlers is by holding a class program for mothers of toddlers. Mother's toddler class program is a class where mothers who have children aged o-5 years discuss together, exchange opinions and experiences on the fulfillment of health services, nutrition, diseases, and stimulation of growth and development, that are guided by facilitators (health workers) using the $\mathrm{MCH}$ handbook.

Infant mortality and under-five mortality rates in Banjarnegara regency over the past two years have experienced an increase which indicates that access and quality of health services are less than optimal. In 2014 there were 204 cases of infant mortality and 21 cases of under-five infant mortality. Meanwhile in 2015 there were 209 cases of infant mortality and 30 cases of underfive deaths (Health Office of Banjarnegara Regency, 2016).

In a study conducted by Suryanto et al. (2014) on the influence of family roles and social support in the process of growth and development of children under five years, the results show that family roles and social support can have a positive effect on personal social, language, motoric growth and development in toddler. Whereas in the study conducted by Kartikawati et al. (2014) the implementation classes for mothers of under-five children had an effect on increasing maternal knowledge by $9.8 \%$, there was an increase in maternal skills by $13.4 \%$ but in 
the mother's attitude there was no significant increase.

Based on the explanation above, the writer was interested in conducting a study entitled "Path Analysis About Psychosocial Effects of Gestation Period and Mother's Toddler Class on Toddler Growth in Banjarnegara Regency".

\section{SUBJECTS AND METHOD}

\section{Study Design}

This was an observational analytical study with case-control design. The study was conducted in Community Healh Center of Banjarnegara Regency, from July 29 to August 31, 2016.

\section{Population and Sampling}

A total of 120 toddlersaged 3 months to 5 years old along with their mothers were selected for the study by fixed exposure sampling.

\section{Study Variabel}

The exogenous variables were family support, maternal education, family income, maternal physical activity, birth weight and maternal class-room program. The endogenous variables were toddler's weight for age, height for age, weight for height. The sampling technique used was fixed exposure sampling.

\section{Data Analysis}

The data collection tool used was a questionnaire and anthropometric measures. The data were analyzed using path analysis run on SPSS AMOS 22 program.

\begin{tabular}{l}
\hline RESULTS \\
The majority of the study subjects had high \\
school-college education ( $74.2 \%)$, heavy ph- \\
ysical activity (62.5\%), high income (41.7\%). \\
When pregnancy received strong family su- \\
pport (73.3\%), babies born had normal birth \\
weight (95.8\%), and attending pregnancy \\
class (50\%). Based on the results of path \\
analysis with SPSS AMOS 22, the results \\
were obtained in Figure 1.
\end{tabular}

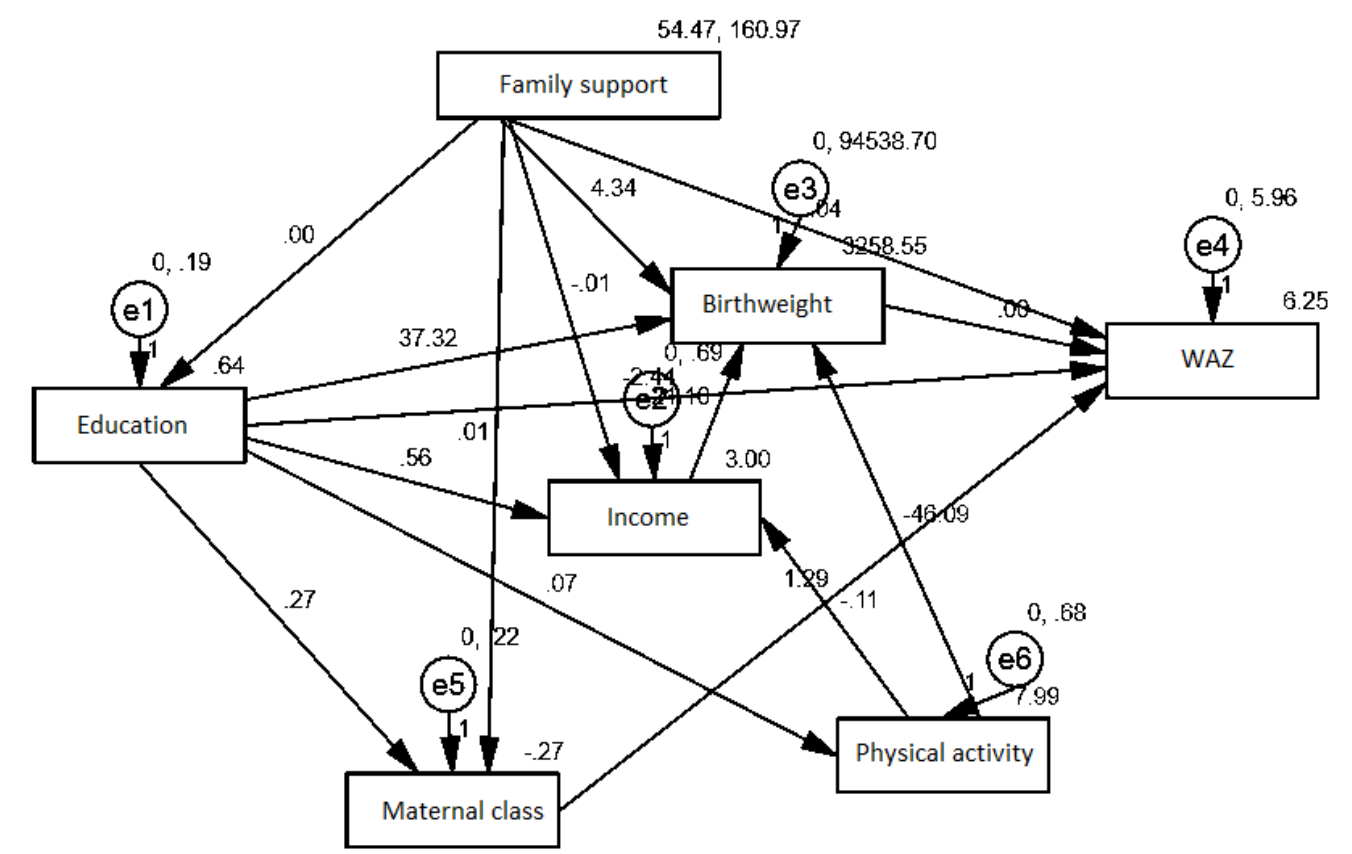

Figure 1. Structural model with unstandardized on factors association with child WAZ 
Journal of Maternal and Child Health (2016), 1(1): 53-61

https://doi.org/10.26911/thejmch.2017.01.01.08

Table 1. The results of path analysis

\begin{tabular}{|c|c|c|c|c|c|c|}
\hline Endogenous Variable & & Exogenous Variable & $\mathbf{b}$ & SE & $\mathbf{p}$ & $\boldsymbol{\beta}$ \\
\hline \multicolumn{7}{|l|}{ Direct effect } \\
\hline WAZ & $\leftarrow$ & Education & -2.44 & 0.53 & $<0.001$ & -0.38 \\
\hline WAZ & $\leftarrow$ & Birth weight & 0.01 & 0.01 & 0.038 & 0.17 \\
\hline WAZ & $\leftarrow$ & Family support & 0.04 & 0.02 & 0.048 & 0.17 \\
\hline WAZ & $\leftarrow$ & Maternal class program & 1.29 & 0.48 & 0.007 & 0.23 \\
\hline \multicolumn{7}{|l|}{ Indirect effect } \\
\hline Education & $\leftarrow$ & Family support & 0.01 & 0.01 & 0.550 & 0.06 \\
\hline Income & $\leftarrow$ & Family support & -0.01 & 0.01 & 0.118 & -0.14 \\
\hline Birth weight & $\leftarrow$ & Family support & 4.34 & 2.25 & 0.053 & 0.18 \\
\hline Maternal class program & $\leftarrow$ & Family support & 0.01 & 0.01 & 0.002 & 0.27 \\
\hline Income & $\leftarrow$ & Education & 0.56 & 0.17 & 0.001 & 0.28 \\
\hline Birth weight & $\leftarrow$ & Education & 37.32 & 67.22 & 0.579 & 0.05 \\
\hline Physical activity & $\leftarrow$ & Education & 0.07 & 0.17 & 0.694 & 0.04 \\
\hline Maternal class program & $\leftarrow$ & Education & 0.27 & 0.09 & 0.006 & 0.23 \\
\hline Income & $\leftarrow$ & Physical activity & -0.11 & 0.09 & 0.245 & -0.10 \\
\hline Birth weight & $\leftarrow$ & Physical activity & -46.09 & 34.23 & 0.178 & -0.12 \\
\hline Birth weight & $\leftarrow$ & Income & -21.10 & 33.99 & 0.535 & -0.06 \\
\hline \multicolumn{7}{|l|}{$\mathrm{N}$ Observation $=120$} \\
\hline \multicolumn{7}{|l|}{ Model Fit } \\
\hline \multicolumn{7}{|l|}{$\mathrm{CMIN}=6.708$} \\
\hline \multicolumn{7}{|l|}{$p=0.349(\geq 0.05)$} \\
\hline \multicolumn{7}{|l|}{$\mathrm{NFI}=0.910$} \\
\hline \multicolumn{7}{|l|}{$\mathrm{CFI}=0.985$} \\
\hline RMSEA $=0.029$ & & & & & & \\
\hline
\end{tabular}

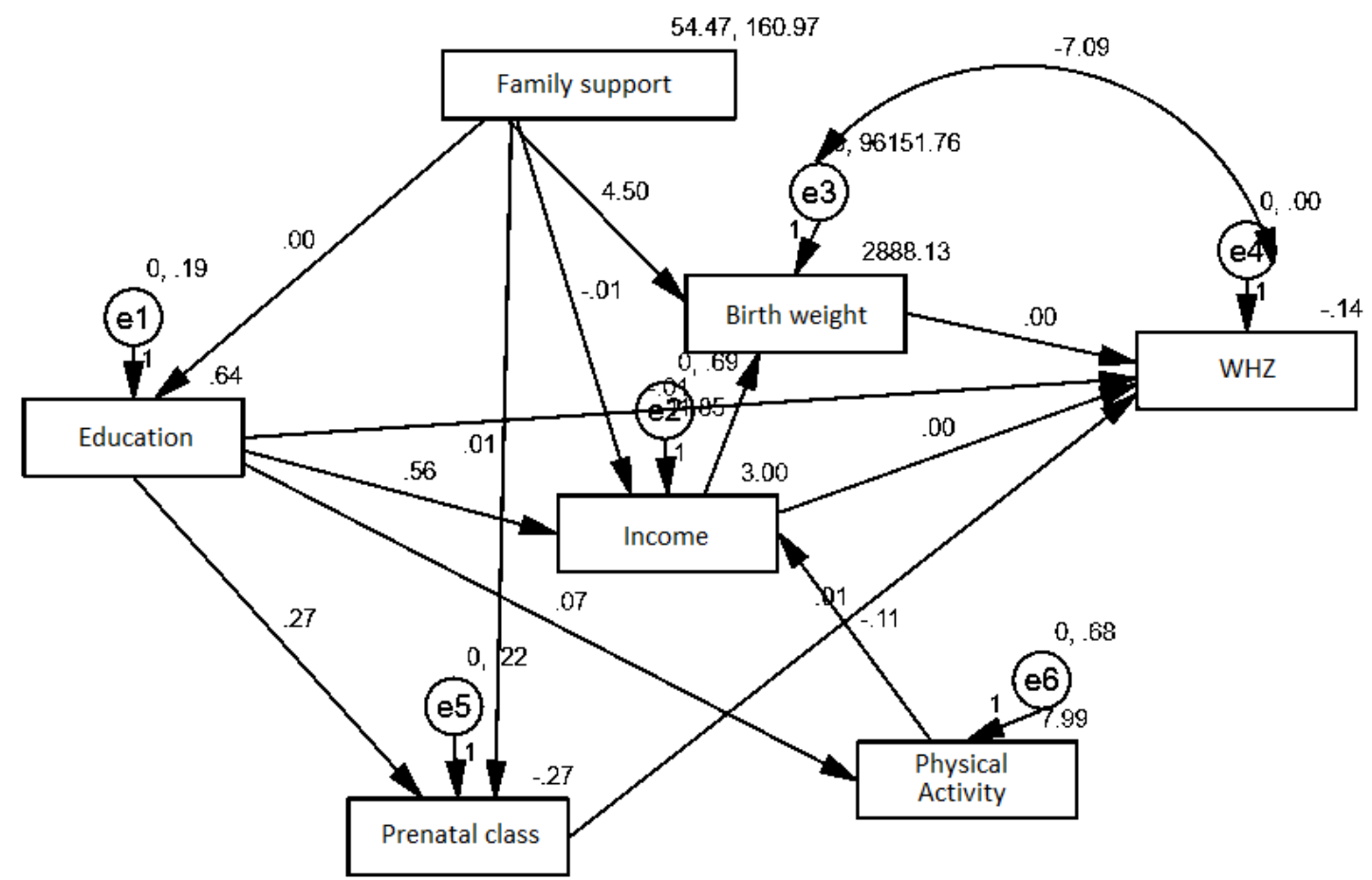

Figure 2. Structural model with standardized on factors association with child WAZ 
Indria et al./Path Analysis on the Effect of Psychosocial, Gestation Period

Table 2. The results of path analysis on psychosocial gestation and toddler classes to height per age

\begin{tabular}{|c|c|c|c|c|c|c|}
\hline Endogenous Variable & & Exogenous Variable & b & SE & $\mathbf{p}$ & $\boldsymbol{\beta}$ \\
\hline \multicolumn{7}{|l|}{ Direct effect } \\
\hline Weight/Age & $\leftarrow$ & Birth weight & 0.14 & 0.13 & 0.279 & 3.39 \\
\hline Weight/Age & $\leftarrow$ & Maternal class program & 4.92 & 2.11 & 0.020 & 0.19 \\
\hline Weight/Age & $\leftarrow$ & Education & -11.76 & 9.37 & 0.209 & -0.41 \\
\hline \multicolumn{7}{|l|}{ Indirect effect } \\
\hline Education & $\leftarrow$ & Family support & 0.01 & 0.01 & 0.550 & 0.05 \\
\hline Income & $\leftarrow$ & Family support & -0.01 & 0.01 & 0.118 & -0.14 \\
\hline Birth weight & $\leftarrow$ & Family support & 1.70 & 1.68 & 0.331 & 0.07 \\
\hline Maternal class program & $\leftarrow$ & Family support & 0.01 & 0.01 & 0.002 & 0.27 \\
\hline Birth weight & $\leftarrow$ & Education & 32.45 & 65.97 & 0.623 & 0.05 \\
\hline Income & $\leftarrow$ & Education & 0.56 & 0.17 & 0.001 & 0.28 \\
\hline Physical activity & $\leftarrow$ & Education & 0.07 & 0.17 & 0.694 & 0.04 \\
\hline Maternal class program & $\leftarrow$ & Education & 0.27 & 0.09 & 0.006 & 0.23 \\
\hline Income & $\leftarrow$ & Physical activity & -0.11 & 0.09 & 0.245 & -0.10 \\
\hline Birth weight & $\leftarrow$ & Physical activity & 18.65 & 19.48 & 0.338 & 0.05 \\
\hline Birth weight & $\leftarrow$ & Income & -12.42 & 14.62 & 0.396 & -0.03 \\
\hline \multicolumn{7}{|l|}{ N Observation $=120$} \\
\hline \multicolumn{7}{|l|}{ Model Fit } \\
\hline \multicolumn{3}{|l|}{ CMIN = 6.580 } & \multirow{2}{*}{\multicolumn{4}{|c|}{$\begin{array}{l}\text { CFI }=0.988 \\
\text { RMSEA }=0.026\end{array}$}} \\
\hline \multicolumn{3}{|l|}{$p=0.361(\geq 0.05)$} & \multirow{2}{*}{\multicolumn{4}{|c|}{ RMSEA = 0.026}} \\
\hline $\mathrm{NFI}=0.912$ & & & & & & \\
\hline
\end{tabular}

Table 1 shows the results of the analysis obtained the path coefficient value (b) between education with body weight per age $(b=-2.44 ; \mathrm{SE}=0.53 ; \mathrm{p}<0.001)$, birth weight with body weight per age $(\mathrm{b}=0.01$; $\mathrm{SE}=$ 0.01; $\mathrm{p}=0.038$ ), family support with body weight per age $(b=0.04$; $S E=0.02 p=$ 0.048), toddler class with weight per age $(b=1.29 ; S E=0.48 ; p=0.007)$ family support with education $(b=0.01 ; \mathrm{SE}=0.01 ; \mathrm{p}=$ $0.550)$, family support with income $(b=$ $0.01 ; \mathrm{SE}=0.01 ; \mathrm{p}=0.118)$, support for families with birth weight $(b=4.34 ; \mathrm{SE}=2.25 ; \mathrm{p}=$ o.053), family support with under-five mother's class, family support with mother's class $(b=0.01 ; \mathrm{SE}=0.01 ; \mathrm{p}=0.002)$, education with income $(\mathrm{b}=0.56 ; \mathrm{SE}=0.17 ; \mathrm{p}=$ 0.001), education with birth weight $(\mathrm{b}=$ 37.32; $\mathrm{SE}=67.22 ; \mathrm{p}=0.579$ ), education with physical activity $(\mathrm{b}=0.07 ; \mathrm{SE}=0.17 ; \mathrm{p}=$ $0.694)$, education with maternal class $(b=$ 0.27; $\mathrm{SE}=0.09 ; \mathrm{p}=0.006)$, physical activity with income $(b=-0.11 ; \mathrm{SE}=0.09 ; \mathrm{p}=0.245)$, physical activity with birth weight $(\mathrm{b}=$ 46.09; $\mathrm{SE}=34.23 ; \mathrm{p}=0.178$ ), income with birth weight $(b=-21.10 ; \mathrm{SE}=33.99 ; \mathrm{p}=$ 0.535).

Table 2 shows the calculated results using computer software program IBM SPSS AMOS 22, obtained path coefficient values (b) between birth weight and height per age $(b=0.14 ; \mathrm{SE}=0.13 ; \mathrm{p}=0.279)$, maternal class with height per age $(b=4.92$; $\mathrm{SE}=2.11 ; \mathrm{p}=0.020)$, education with height per age $(b=-11.76 ; S E=9.37 ; p=0.209)$, family and education $(b=0.01 ; \mathrm{SE}=0.01 ; \mathrm{p}=$ 0.550), family support with income $(b=-$ 0.01; $\mathrm{SE}=0.01 ; \mathrm{p}=0.118)$, family support with birth weight $(b=1.70 ; \mathrm{SE}=1.68 ; \mathrm{p}=$ o.331), family support with maternal class $(b=0.01 ; \mathrm{SE}=0.01 ; \mathrm{p}=0.002)$, education with birth weight $(b=32.45 ; \mathrm{SE}=65.97 ; \mathrm{p}=$ o.623), education with income $(b=0.56$; $\mathrm{SE}=0.17 ; \mathrm{p}=0.001)$, education with physical activity $(\mathrm{b}=0.07 ; \mathrm{SE}=0.17 ; \mathrm{p}=$ o.694), education with maternal class $(b=$ 
0.27; $\mathrm{SE}=0.09 ; \mathrm{p}=0.006)$, physical activity with income $(b=-0.11 ; \mathrm{SE}=0.09 ; \mathrm{p}=0.245)$, physical activity with birth weight $(b=$
18.65; $\mathrm{SE}=19.48 ; \mathrm{p}=0.338)$, income with birth weight $(b=-12.42 ; \mathrm{SE}=14.62 ; \mathrm{p}=$ o.396).

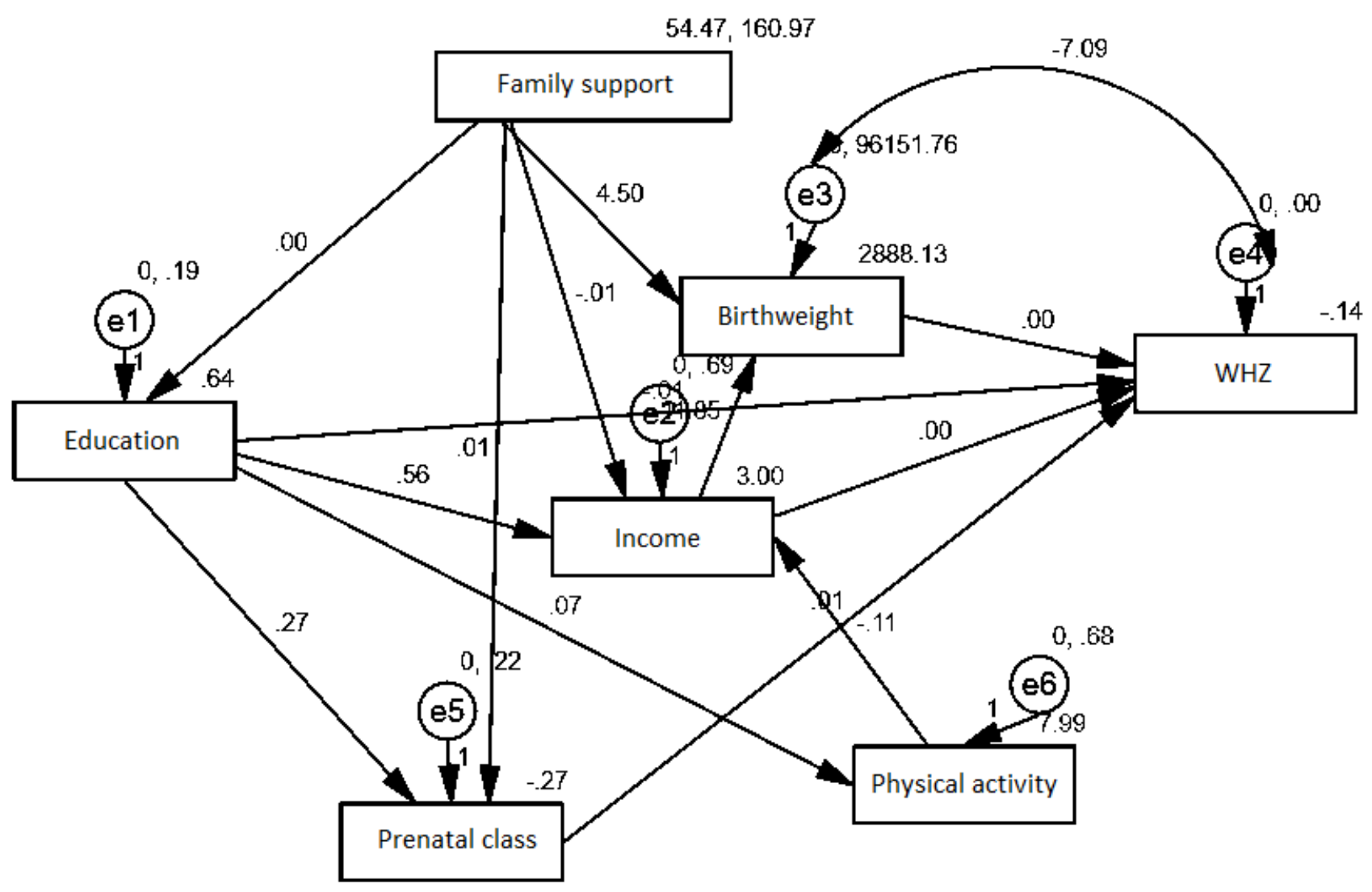

Figure 3. Structural model with standardized solution on factors association with child WAZ

Table 3 shows the calculation results using the IBM SPSS AMOS 22 computer program software, obtained path coefficient value (b) between birth weight with body weight per height $(b=0.00 ; \mathrm{SE}=0.00 ; \mathrm{p}=$ 0.047), maternal class with body weight per height $(b=0.01 ; \mathrm{SE}=0.01 ; \mathrm{p}=0.016)$, income with body weight per height $(b=-0.01$; $\mathrm{SE}=0.01 ; \mathrm{p}=0.549$ ), education with body weight per height $(b=0.01 ; \mathrm{SE}=0.01 ; \mathrm{p}=$ o.0o8), family support with education $(b=$ o.01; $\mathrm{SE}=0.01 ; \mathrm{p}=0.550$ ), family support with income $(b=-0.01 ; \mathrm{SE}=0.01 ; \mathrm{p}=0.118)$, family support with birth weight $(b=1.70$;
$\mathrm{SE}=1.68 ; \mathrm{p}=0.331$ ), family support with the toddler mother's class $(b=0.01 ; \mathrm{SE}=0.01$; $\mathrm{p}=0.002)$, education with birth weight $(\mathrm{b}=$ 32.45; $\mathrm{SE}=65.97 ; \mathrm{p}=0.623)$, education with income $(b=0.56 ; \mathrm{SE}=0.17 ; \mathrm{p}=0.001)$, education with physical activity $(\mathrm{b}=0.07 ; \mathrm{SE}=$ $0.17 ; \mathrm{p}=0.694$ ), education with toddler mother's class $(b=0.27 ; \mathrm{SE}=0.09 ; \mathrm{p}=0.006)$, physical activity with income $(\mathrm{b}=-0.11 ; \mathrm{SE}=$ 0.09; $\mathrm{p}=0.245$ ), physical activity with income $(b=-0.11 ; S E=0.09 ; p=0.245)$, physical activity with birth weight $(b=18.65$; $\mathrm{SE}=$ 19.48; $\mathrm{p}=0.338$ ), income with birth weight $(b=-12.42 ; \mathrm{SE}=14.62 ; \mathrm{p}=0.396)$. 
Table 3. The results of path analysis of the association between psychosocial gestation, maternal class program, and child WHZ

\begin{tabular}{|c|c|c|c|c|c|c|}
\hline Endogenous Variable & & Exogenous Variable & $\mathbf{b}$ & $\overline{\text { SE }}$ & $\mathbf{p}$ & $\bar{\beta}$ \\
\hline \multicolumn{7}{|l|}{ Direct Effect } \\
\hline WHZ & $\leftarrow$ & Birth weight & 0.00 & 0.00 & 0.047 & 1.44 \\
\hline WHZ & $\leftarrow$ & Maternal class program & 0.01 & 0.01 & 0.016 & 0.20 \\
\hline WHZ & $\leftarrow$ & Income & -0.01 & 0.01 & 0.549 & -0.22 \\
\hline WHZ & $\leftarrow$ & Education & -0.01 & 0.01 & 0.008 & -0.22 \\
\hline \multicolumn{7}{|l|}{ Indirect Effect } \\
\hline Education & $\leftarrow$ & Family support & 0.01 & 0.01 & 0.550 & 0.06 \\
\hline Income & $\leftarrow$ & Family support & -0.01 & 0.01 & 0.118 & -0.14 \\
\hline Birth weight & $\leftarrow$ & Family support & 4.50 & 2.26 & 0.046 & 0.18 \\
\hline Maternal class program & $\leftarrow$ & Family support & 0.01 & 0.01 & 0.002 & 0.27 \\
\hline Physical activity & $\leftarrow$ & Education & 0.07 & 0.17 & 0.694 & 0.04 \\
\hline Income & $\leftarrow$ & Education & 0.56 & 0.17 & 0.001 & 0.28 \\
\hline Maternal class program & $\leftarrow$ & Education & 0.27 & 0.09 & 0.006 & 0.23 \\
\hline Income & $\leftarrow$ & Physical activity & -0.11 & 0.09 & 0.245 & -0.10 \\
\hline Birth weight & $\leftarrow$ & Income & -11.85 & 32.75 & 0.718 & -0.03 \\
\hline \multicolumn{7}{|l|}{$\mathrm{N}$ Observation $=120$} \\
\hline \multicolumn{7}{|l|}{ Model Fit } \\
\hline $\mathrm{CMIN}=3.460$ & & $\mathrm{CFI}=1.000$ & & & & \\
\hline$p=0.839(\geq 0.05)$ & & RMSEA $=<0.001$ & & & & \\
\hline $\mathrm{NFI}=0.954$ & & & & & & \\
\hline
\end{tabular}

\section{DISCUSSION}

\section{The effect of family support on child growth}

There were direct and indirect effect of the family support on toddler growth. Psychiatric life was a distinctive period with different changes that require adjustment, including in the form of emotional control, the ability to learn from experience, direct action to overcome difficulties, and maintaining a harmonious interpersonal relationship with others.

Chapman et al. (1997) in Astuti et al. (2000) stated that social support generally has a positive influence on physical and psychological well-being and specifically affects health during pregnancy. Social support especially from families can improve feelings of well-being, personal control, positive feelings, and help pregnant women perceive changes that occur during pregnancy with lower stress levels.

\section{The effect of maternal education on child growth}

There was a negative direct influence and a positive indirect effect of maternal education on growth. Parents with high education would be more open to receive information, especially about health problems, so that their health status was expected to be better.

In a study conducted by Emamian et al. (2013) it was found that maternal education is an important factor in preventing the occurrence of stunting. That's because with higher education will improve the nutritional status of the family.

\section{The effect of physical activity on child growth}

There was an indirect effect of physical activity on growth. In one study revealed that when pregnant women did physical activity, the fetus would get the effect that was the fetal heart would be healthier and stronger. In addition, it was also mentioned that the physical activity of the mother during pregnancy would affect premature birth. Cheng 
Journal of Maternal and Child Health (2016), 1(1): 53-61

https://doi.org/10.26911/thejmch.2017.01.01.08

et al. (2016) showed that stress during pregnancy from both physical activity or social environment can increase the risk of giving birth with low birth weight. Premature birth with low birth weight effects on growth.

\section{The effect of family income on child} growth

There was a negative indirect effect of family income on growth. That was because the writer did not examine the purchasing power of the respondent to meet the food consumption needs.

According to a study conducted by Strand (2006) and Febrianto (2012), socioeconomic status affects the health status; a low economic status will affect health in the future. One indicator of growth is the assessment of nutritional status obtained from measurements of body weight per age. There is a meaningful relationship between the level of family income and the nutritional status of children under five.

\section{The effect of birth weight on child growth}

There was a positive direct effect of the baby's body weight on growth. Birth weight would affect growth and development. Children with low birth weight, would have slower growth and development. In a study conducted by Arnisam (2007), it was found that children born with LBW had a greater risk of experiencing less nutritional status compared with children with a LBW history.

\section{The effect of maternal class-room program on child growth}

There was a positive direct effect of the toddler maternal class-room program on growth. Kartikawati et al (2014) stated that the implementation of mother's toddler classes every month can improve mother's skills in caring for toddlers. Mothers' skills in caring under-fives children at home include monitoring the growth and development of toddlers, providing food with a balanced menu, managing sick toddlers and providing medicines at home.

There are direct and indirect effect of family support, maternal education, family income, maternal physical activity, birth weight and mothers of under-five classes on growth with the measurement criteria of body weight per age, height per age, body weight per height and development in toddler.

\section{REFERENCE}

Arnisam (2007). Hubungan Berat Badan Lahir Rendah (BBLR) dengan Status Gizi Anak Usia 6-24 Bulan. Yogyakarta: UGM.

Astuti AB, Santosa SW, Utami MS (2000). Hubungan Antara Dukungan Keluarga Dengan Penyesuaian Diri Perempuan Pada Kehamilan Pertama. Jurnal Psikologi UGM. 2: 84-95.

Barros A, Victora C, Horta B, Goncalves H, Lima R, Lynch J (2006).Effect of Socioeconomic Change from Birth to Early Adulthood on Height and Overweight.International Journal of Epidemiology. 35(1): 1233-1238.

Cheng E, Park H, Wisk L, Mandell K, Wakeel F, Litzelman K, Chatterje D, Witt W (2016). Examining the link between women's exposure to stressful life events prior to conception and infant and toddler health: the role of birth weight.Journal Epidemiol Community. 70: 245-252.

Dinas Kesehatan Kabupaten Banjarnegara (2016). Laporan Bagian Kesehatan Ibu dan Anak. Banjarnegara: Dinas Kesehatan Kabupaten Banjarnegara.

Emamian M, Fateh M, Gorgani N, Fotouhi A (2013). Mother's Education is The Most Important Factor in Socio Economic Inequality of Child Stunting in Iran. Public Health Nutrition. 17(9): 2010-1015. 
Febrianto ID (2012). Hubungan Tingkat Penghasilan, Tingkat Pendidkan Dan Tingkat Pengetahuan Orangtua Tentang Makanan Bergizi Dengan Status Gizi Siswa TK Islam Zahrotul Ulum Karangampel Indramayu. UNY: Yogyakarta.

Herper S, Lynch J, Hsu W, Everson S, Hillemeier M, Rahunathan E, T Salonen J, Kaplan G (2002). Life Course Socioeconomic Conditions and Adult Psychosocial Functioning.International Journal of Epidemiology.31 : 395-403.

Kartikawati S, Sutedja E (2014). Pengaruh Kelas Ibu Balita terhadap Peningkatan Pengetahuan, Sikap dan Keterampilan Ibu Balita dalam Merawat Balita di Wilayah Kerja Puskesmas Sukarasa Kota Bandung. Bhakti Kencana Medika, 4(1): 1-7.

Kementerian Kesehatan RI (2014). Keluarga Sehat Idamanku Kota Sehat Kotaku. Jakarta: Pusat Promosi Kesehatan Kemenkes RI.

Lacey R, Sacker A, Kumari M, Worts D, McDonough P, Booker C, McMunn A(2015). Work Family Life Course and Markers of Stress and Inflammation in Mid Life: Evidence from the National Child Development Study. International Journal of Epidemiology.pp.1-13.

Muller A, Weigelt J, Gotz A, Schmidt O, Alva I, Matuschke I, Ehling U,
Beringer $\mathrm{T}$ (2015). The Role of Biomass in the Sustainable Development Goals: A Reality Check and Governance Implications. Paper. Institute for Advanced Sustainability Studies.

Power C, Atherton K, Strachan D, Shepherd P, Fuller E, Davis A, Gibb I, Kumari M, Lowe G, Macfarlane G, Rahi J, Rodges B, Stansfeld S (2007). Life-Course Influences on Helath in British Adulth: Effects of Socio-economic position in Childhood and Adulthood. International Journal of Epidemiology.36 : 532-539.

SDKI (2012).Survei Demografi dan Kesehatan Indonesia. Jakarta: Badan $\mathrm{Pu}-$ sat Statistik.

Sentika R (2015). Gerakan Duta 1000 Hari Pertama Kehidupan Provinsi Jawa Tengah. Jakarta: Deputi Bidang Koordinasi Peningkatan Kesehatan.

Strand BH, Kunst A (2006). Childhood Socioeconomic Position an Causespecific Mortality in Early Adulthood. American Journal of Epidemiology. 165(1): 85 - 91.

Suryanto, Purwandari, Mulyono (2014). Dukungan Keluarga dan Sosial dalam Pertumbuhan dan Perkembangan Personal Sosial, Bahasa dan Motorik Pada Balita di Kabupaten Banyumas. Jurnal Kesehatan Masyarakat. 10(1): 103-109. 